\title{
7-Step PBL: Problem Solving Ability of Students in Work and Energy
}

\author{
Amin Mustajab ${ }^{1}$, Samsul Bahri ${ }^{2}$, Ya Julyanto ${ }^{3}$ \\ STKIP Melawi, Indonesia ${ }^{1,2,3}$ \\ aminmustajab53@gmail.com¹, samsulbahri804@gmail.com²,yajulyanto@gmail.com³ \\ Received: July $9^{\text {th }}, 2020$. Revised: August $19^{\text {th }}, 2020$. Accepted: August $24^{\text {th }}, 2020$
}

\begin{abstract}
Keywords :
7-Step PBL; Problem Solving

Ability; Work and Energy

ABSTRACT

The purpose of this study was to determine the level of problem solving skills of students in the 7-Step PBL material work and energy materials. The method used in this research is descriptive method. The number of samples used in this study were 62 students. The data analysis technique used is descriptive analysis technique. There are three main findings in this study, the first amounted to $69.35 \%$ the average level of problem solving abilities of students is still at level 2 (moderate). Second, even after participating in learning using the 7-Step PBL method, the average problem solving ability of students has not yet reached level 4(high). Third, in indicator problem number 2 "relationship work and kinetic energy" there are no students who have problem-solving skills at level 4(high).
\end{abstract}

\section{INTRODUCTION}

Problem-based learning (PBL) can be considered a constructivist approach [1] [2] [3] for education [4]. PBL is a teaching and learning strategy that is used to engage students in problem solving. PBL is defined as student-focused pedagogy [5] [6] [7] where students develop intellectual independence when working through problems with little direction from the teacher [8]. PBL environment designed to help students build a knowledge base that is broad and flexible, be an effective collaborator, develop independent learning skills, develop effective problem solving skills, and become intrinsically motivated to learn [9].

PBL is generally implemented as a small group tutorial where students learn through learning scenarios. Scenarios involve problems that become more complex over time [10], interesting, open, and real to motivate students and stimulate discussion [11]. According to Maurer \& Neuhold [12], the 7-Step PBL learning steps consist of clarifying terms and concepts, formulating problem statements, discussing problems (brainstroming), categorizing and structuring discussions, determining learning objectives to be achieved, self-learning, post - discussion and reflection in the learning process.

PBL can improve academic achievement, cognitive abilities, procedural skills [13], scientific argumentation abilities [14], and enable students to work in groups cooperatively and build knowledge through social negotiations compared to traditional teaching models [15]. Yew \& Schmidt [4] show that three PBL phases: problem analysis, independent learning, and reporting phases, play a special role in 
influencing students' scientific reasoning abilities. Martin \& Hand [16] reported progress in understanding concepts when students were given the opportunity to work collaboratively to solve problems and discuss alternative views. The findings from Loyens et al. [9] that PBL can enhance conceptual change because students seriously and critically consider contrasting information between scientific explanations and previous misconceptions. When clarifying the terms and concepts the teacher can play an active role if students provide incorrect explanations for the word / concept of the problem given so that students in the classroom learning using the PBL method demonstrate an explanation and understanding of problem analysis that is superior compared to students in conventional classes [17].

The seven-step PBL, also known as the "seven-jump" approach. Each tutorial meeting is thus divided into two parts: The tutorial session begins with a post-assignment discussion that students prepare for self-study prior to the tutorial, and after a short break the initial discussion of the next assignment follows the students preparing until the next tutorial meeting. These learning steps consist of the stage of clarifying terms and concepts, formulation of the problem statement, brainstorm, categorized and structured, formulation of common learning objectives, self-study, post-discussion [12]. The advantage of this approach is that students feel ownership of their own learning, and by being able to choose for themselves exactly how they want to approach a particular problem, they show a higher level of interest and more involvement in their learning process.

Problem solving is often described as procedures, strategies, steps, ways, defining problems, analyzing problems, collecting data, formulating solutions, evaluating solutions, choosing the best solution and generalizing results, which require verification of results and generalizations for other similar cases [18]. The main idea of problem solving is a combination of declarative and procedural knowledge units (elements of knowledge) that come together.

There are four steps to solving structured problems, representing problems, preparing plans or strategies, implementing plans or strategies and evaluating solutions. First the problem representation, in this section students must extract and assimilate information, determine the purpose of the problem and introduce the appropriate notation when needed. Secondly formulate a plan, at this stage students must make a general plan and choose a relevant model, "heuristics" that is useful for solving problems based on an understanding of the problem. Thirdly carry out the plan, at this stage students carry out mathematical calculations to get the results of the completion. , at this stage students conclude the answer to the problem, examine the solutions provided and examine the mathematical keywords of the problem. To measure the four steps of solving this problem is required rubric.

Polya's rubric is used to measure the four steps of problem solving ability. In the step of problem representation, Polya categorizes problem solving abilities into 4 levels [19]. Level 1, students must know the purpose of the problem. Level 2, students must understand the variables and/or information needed and use the required notation. Level 3, students can clearly identify all the variables needed and separate them from foreign information. Level 4, students demonstrate a clear understanding of the problem given and can identify specific factors that influence the approach of the problem before solving it.

In work and energy, Nguyen et al. [20] found that students had significant difficulties in transferring their problem solving skills from verbal representation to graphical and functional representations. Students had difficulties extracting information from the graph, except for the coordinates of a point and the slope. When given a function, students attempted to find its value at some points rather than integrating it. Students also had considerable difficulties with interpreting physical meaning of mathematical operations such as derivative and integration although they could easily perform these operations. Many of the difficulties appeared to arise due to the tendency of students trying to mimic the previous problem when faced with a new but similar problem.

Research on the 7-Step PBL learning model that explains the influence and improvement of problem solving abilities has been widely carried out. But research that explains the level of problem-solving 
ability of students in work and energy material in the 7-Step PBL class has not been much researched. Therefore, the researcher wants to research about the level of problem solving ability in the 7-Step PBL class of work and energy material.

\section{METHOD}

This type of research is quantitative research. The research design used in this study used a quantitative descriptive research design. This research was conducted at SMA Negeri 4 Malang. The number of samples in this study were 62 students. To describe students' problem-solving abilities in this study using a proprietary rubric [19]. Problem solving ability data obtained from the results of written tests. The written test is given in the form of a problem-solving ability test in the form of an essay of four questions. Problem indicators consist of using the concept of work to solve physics problems, solving physics problems using the concept relationship of work and kinetic energy, solving physics problems using the concept relationship of work and gravitational potential energy, using the concept of conservation mechanical energy in physics problems. To find out the problem-solving ability of each problem solving component, it is necessary to calculate the value of each problem-solving component. The calculation of the value of the problem solving component uses equation 1 . The criteria for the problem solving component can be seen in Table 1 .

$$
P_{x}=\frac{n R_{x}}{n S_{x}} \times 100
$$

$$
\begin{aligned}
& \text { Information : } \\
& \begin{array}{ll}
x \quad=\text { aspects } \mathrm{A}, \mathrm{B}, \mathrm{C} \text { and } \mathrm{D} \\
P x=\text { aspectpercentage } \mathrm{x} \\
R x=\text { obtaining an aspectscore } \mathrm{x} \\
S x=\text { maximumaspectscorex } \\
n \quad=\text { number of studentstakingtests }
\end{array}
\end{aligned}
$$

\begin{tabular}{|c|c|c|c|c|c|}
\hline \multirow[b]{2}{*}{ व } & \multirow[b]{2}{*}{ שֶ. } & \multicolumn{4}{|c|}{ Problem solving steps } \\
\hline & & $\begin{array}{l}\text { Defining and } \\
\text { understanding the } \\
\text { problem }\end{array}$ & $\begin{array}{l}\text { Develop a plan or } \\
\text { strategy to solve } \\
\text { the problem }\end{array}$ & Carry out the plan & $\begin{array}{c}\text { Reflect (evaluate) } \\
\text { solutions }\end{array}$ \\
\hline 1 & 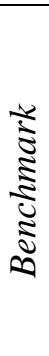 & $\begin{array}{l}\text { Shows a limited } \\
\text { understanding of the } \\
\text { problem and its wider } \\
\text { context. }\end{array}$ & $\begin{array}{l}\text { Students do not } \\
\text { have the ability to } \\
\text { consider new } \\
\text { strategies even } \\
\text { though the } \\
\text { strategies used are } \\
\text { clearly } \\
\text { inappropriate }\end{array}$ & $\begin{array}{l}\text { Stating at most one, } \\
\text { is often the wrong } \\
\text { solution. Students do } \\
\text { not recognize many } \\
\text { ways to carry out } \\
\text { plans even } \\
\text { if solutions } \\
\text { seem wrong }\end{array}$ & $\begin{array}{l}\text { Students do not } \\
\text { analyze or } \\
\text { synthesize results }\end{array}$ \\
\hline 2 & 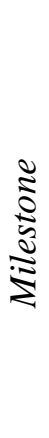 & $\begin{array}{l}\text { Demonstrate an } \\
\text { understanding that } \\
\text { was developed in part } \\
\text { of the problem and } \\
\text { identify some factors } \\
\text { specific that affect the } \\
\text { approach to the } \\
\text { problem before the } \\
\text { finish }\end{array}$ & $\begin{array}{l}\text { Students rarely } \\
\text { recognize the need } \\
\text { for some } \\
\text { solutions, but } \\
\text { sometimes can do } \\
\text { so when } \\
\text { requested or } \\
\text { when deleting a } \\
\text { solution that is } \\
\text { not right. }\end{array}$ & $\begin{array}{l}\text { Sometimes students } \\
\text { realize the need for } \\
\text { multiple steps to } \\
\text { implement the plan } \\
\text { that especially if the } \\
\text { effort first failed but } \\
\text { the students do with } \\
\text { the ability is limited. }\end{array}$ & $\begin{array}{l}\text { Students often } \\
\text { apply the } \\
\text { knowledge } \\
\text { background behind } \\
\text { or context of the } \\
\text { problem when } \\
\text { considering the } \\
\text { solution. Students } \\
\text { identify a solution } \\
\text { that is partly true }\end{array}$ \\
\hline
\end{tabular}

Tabel 1. Criteria for problem solving ability 


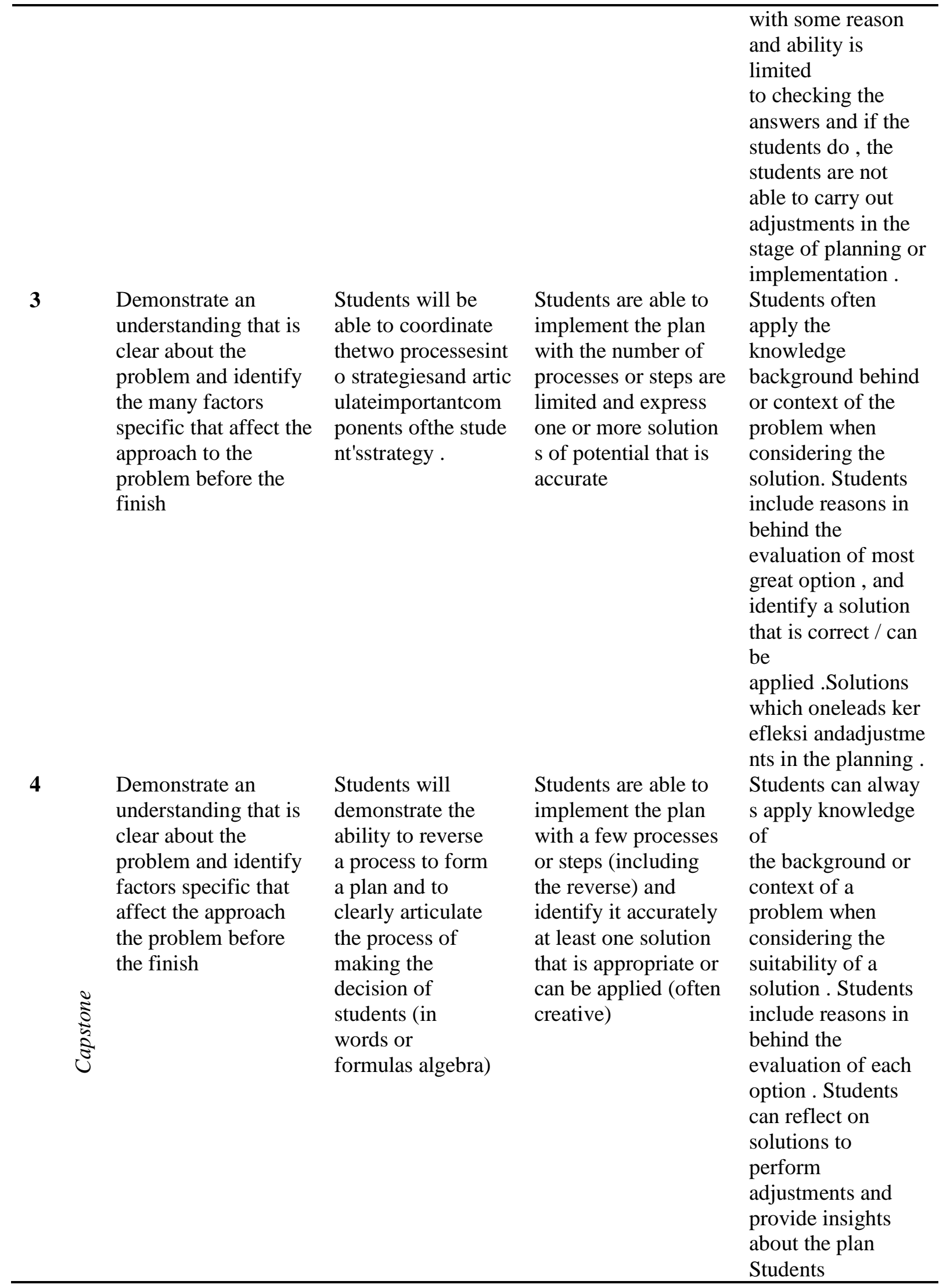




\section{RESULTS AND DISCUSSIONS}

Results

The average problem solving ability of students after participating in learning with the 7-step PBL model is presented in Figure 1. As many as $30.56 \%$ of students are at level 1 (Benchmark). As many as $40.32 \%$ of students are at level 2 (Milestone). As many as $29.03 \%$ of students are at level 3 (Milestone).

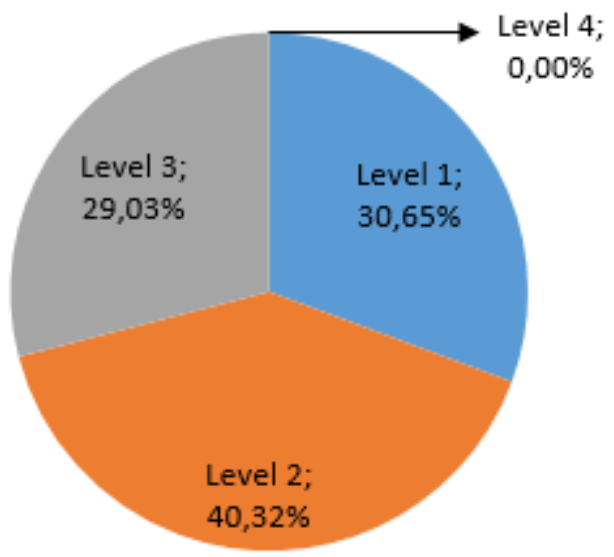

Fig 1. Average level of problem-solving skills in PBL 7-step classes

The distribution of students' problem solving abilities on each item is presented in Figure 2. In the indicator question no 1 "work concept in the incline" as many as $4.84 \%$ of students are at level 1 (Benchmark). As many as $49.94 \%$ of students are at level 2 (Milestone). As many as $45.16 \%$ of students are at level 3 (Milestone). At level 4 (Capstone) there are only 8.06\% students. In indicator number 2 " relationship work and kinetic energy" $32.26 \%$ of students are at level 1 (Benchmark)). A total of 50.00 students are at level 2 (Milestone). At level $317.74 \%$ of students are at level 3 (Milestone). In item no. 2 there are no students who have ability at level 4 (Capstone). In indicator number 3, "work relations and potential energy" as much as $41.94 \%$ are at level 1 (Benchmark)). As many as $37.10 \%$ of students are at level 2 (Milestone). A total of $14.52 \%$ are at level 3 (Milestone). At level 4 (Capstone) there are $6.45 \%$ students. In indicator problem number 4 "mechanical energy conservation law" there are $61.29 \%$ of students at level 1 (Benchmark)). At level 2 (Milestone) there are $9.68 \%$ students. As many as $11.29 \%$ are at level 3 (Milestone). At level 4 (Capstone) there are 17.74\% students.

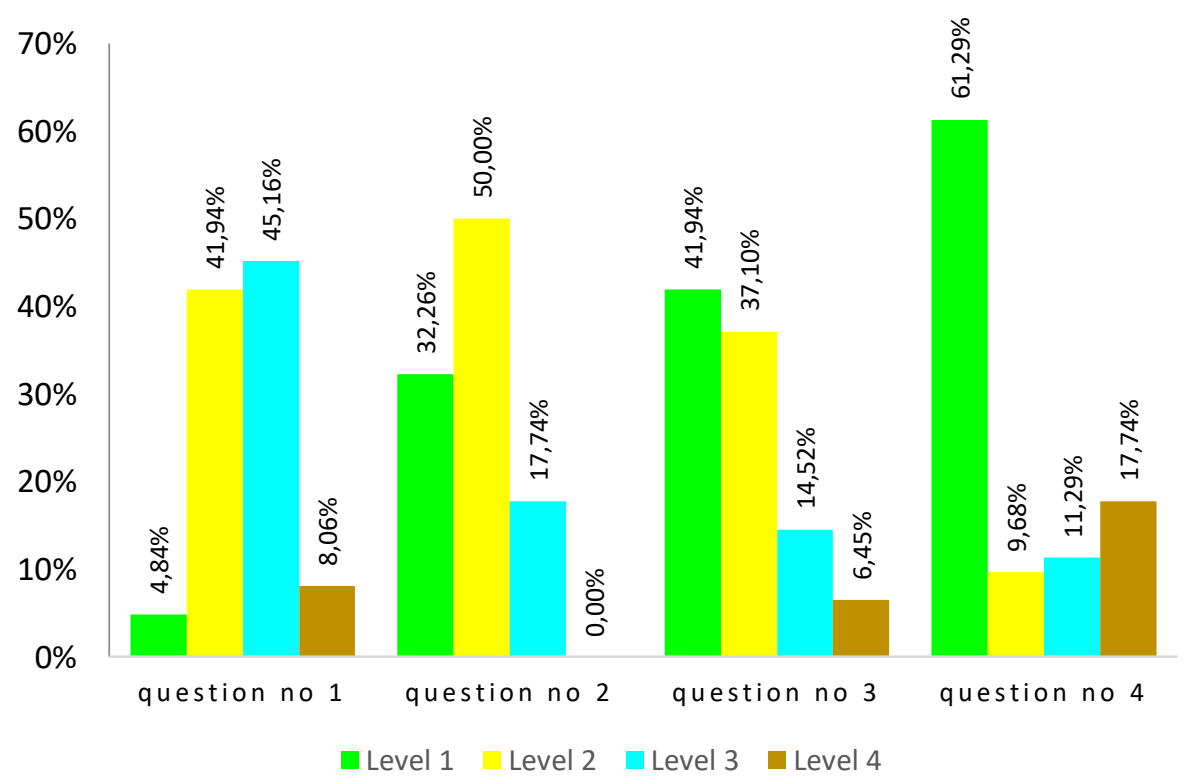

Fig 2. Average level of problem-solving skills in the 7-step PBL class on each item 


\section{Discussions}

From Figure 1. that the average percentage of problem solving skills of students who take classes using the 7-step PBL model shows that $30.56 \%$ of students are at level 1 (Benchmark). This is due to several reasons, first students show a limited understanding of the problem and wider context. This is also reinforced by the findings of Sujarwanto, et al., students find it difficult to make representations (graphs, diagrams) during learning and when solving problems (tests/quizzes) [21]. This is because students have difficulty recognizing the state of the system being reviewed. Second, students choose strategies without regard to compatibility, usually based on superficial phrases or keywords in this case also in accordance with the findings of students formulate problem-solving strategies based on what is known and what is asked not based on underlying physics concepts . One possibility is this happened because many students did not understand the concepts of Physics that had been taught, as were the results of interviews conducted with students. This is also reinforced by Mustofa \& Rusdiana [22] that problem-solving ability requires mastery of concepts as the basis. Third, students do not recognize many paths to running a plan even though the solution given is wrong. students have difficulty in planning solutions, which will certainly affect the accuracy of the solutions provided. The four students did not evaluate the solution given.

From Figure 1. that the average percentage of problem solving skills of students who take classes using the 7-step PBL model shows that $40.32 \%$ of students are at level 2 (Milestone). This is due to several things, first students can only identify a number of specific factors that affect the problem. Second, problem solving strategies are not detailed enough because of the limited specific information. Third, the limited ability of students to implement other solutions when mathematical errors and/or conceptual errors are also found by Walsh et al. [23], students use the information they have to solve problems, but they may not always get the right answer because of a mathematical error or conceptual problem.Fourth, the limited ability to evaluate solutions based on the concept of the problem, this finding is also in line with the findings of Sujarwanto, et al. [21], that students evaluate solutions based on what is known on the problem not based on the basic concept of the problem.

From Figure 1. that the average percentage of problem solving skills of students who take classes using the 7-step PBL model shows that 29.03\% of students are at level 3 (Milestone). This shows several things, first students can understand the problem clearly and can identify specific factors that affect the problem, although students can identify some specific factors that affect the problem but the students' answers are not always correct problem solving also relies on the correctness of the concepts used and evaluation of the solution to the problem of Sujarwanto, et al. [21].Second, students can identify plans based on structural aspects of the problem not only by keywords and phrases but not always with accuracy. Third, students can use several steps in implementing plans to find solutions. Fourth, students synthesize results from more than one perspective.

\section{CONCLUSION AND SUGGESTION}

Based on the description in the results and discussion section of $69.35 \%$ the average level of problem solving abilities of students is still at category Milestone. Second, even after participating in learning using the 7-Step PBL method, the average problem solving ability of students has not yet reached level 4. Third, in indicator problem number 2 " relationship work and kinetic energy" there are no students who have problem-solving skills at level 4 . In this study, researchers have not been teaching media to help students in problem solving skills. It is hoped that in future studies it can apply media to physics learning using the 7-Step PBL method so that it can improve problem-solving abilities. 


\section{REFERENCES}

[1] Askell-Williams, H., Murray-Harvey, R., \& Lawson, M. J. (2007). Teacher education students' reflections on how problem-based learning has changed their mental models about teaching and learning. The Teacher Educator, 42(4): 237-263.

[2] Hung, W. (2016). All PBL starts here: The problem. Interdisciplinary Journal of problem-based learning, 10(2): 2 .

[3] Ulger, K. (2018). The effect of problem-based learning on the creative thinking and critical thinking disposition of students in visual arts education. Interdisciplinary Journal of Problem-Based Learning, 12(1).

[4] Yew, E. H., \& Schmidt, H. G. (2012). What students learn in problem-based learning: A process analysis. Instructional Science, 40(2): 371-395.

[5] Raine, D., \& Symons, S. (2012). Problem-based learning: undergraduate physics by research. Contemporary Physics, 53(1): 39-51.

[6] Senocak, E., Taskesenligil, Y., \& Sozbilir, M. (2007). A study on teaching gases to prospective primary science teachers through problem-based learning. Research in Science Education, 37(3): 279-290.

[7] Tosun, C., \& Senocak, E. (2013). The effects of problem-based learning on metacognitive awareness and attitudes toward chemistry of prospective teachers with different academic backgrounds. Australian Journal of Teacher Education, 38(3): 4.

[8] Vandenhouten, C., Groessl, J., \& Levintova, E. (2017). How do you use problem-based learning to improve interdisciplinary thinking?. New Directions for Teaching and Learning, 2017(151): 117133.

[9] Loyens, S. M., Jones, S. H., Mikkers, J., \& van Gog, T. (2015). Problem-based learning as a facilitator of conceptual change. Learning and Instruction, 38: 34-42.

[10] Jaffe, L., Gibson, R., \& D'Amico, M. (2015). Process-Oriented Guided-Inquiry Learning: A natural fit for occupational therapy education. Occupational Therapy in Health Care, 29(2): 115-125.

[11] Sahin, M. (2010). Effects of problem-based learning on university students' epistemological beliefs about physics and physics learning and conceptual understanding of Newtonian mechanics. Journal of Science Education and Technology, 19(3): 266-275.

[12] Maurer, H., \& Neuhold, C. (2012). Problems everywhere? Strengths and challenges of a problembased learning approach in European studies. In Strengths and Challenges of a Problem-Based Learning Approach in European Studies. APSA 2012 Teaching \& Learning Conference Paper.

[13] Baran, M., \& Sozbilir, M. (2018). An application of context-and problem-based learning (C-PBL) into teaching thermodynamics. Research in Science Education, 48(4): 663-689.

[14] Pritasari, A. C., Dwiastuti, S., \& Probosari, R. M. (2016). Peningkatan Kemampuan Argumentasi melalui Penerapan Model Problem Based Learning pada Siswa Kelas X MIA 1 SMA Batik 2 Surakarta, Tahun Pelajaran 2014/2015. Jurnal Pendidikan Biologi, 8(1): 1-7.

[15] Cross, D., Taasoobshirazi, G., Hendricks, S., \& Hickey, D. T. (2008). Argumentation: A strategy for improving achievement and revealing scientific identities. International Journal of Science Education, 30(6): 837-861.

[16] Martin, A. M., \& Hand, B. (2009). Factors affecting the implementation of argument in the elementary science classroom. A longitudinal case study. Research in Science Education, 39(1): 17-38.

[17] Mustajab, A., Muhardjito, M., \& Sunaryono, S. (2020). Effects of 7-step Problems Based Learning and Scientific Reasoning on Problem Solving Abilities. Jurnal Pembelajaran Fisika, 8(1): 47-60.

[18] Alshamali, M. A., \& Daher, W. M. (2016). Scientific reasoning and its relationship with problem solving: The case of upper primary science teachers. International Journal of Science and Mathematics Education, 14(6): 1003-1019.

[19] Hostos Rubrics. (2017). Center for Teaching and Learning (CTL): Hostos and Value Rubrics. www.hostos.cuny.edu.

[20] Nguyen, D. H., \& Rebello, N. S. (2009, November). Students' difficulties in transfer of problem solving across representations. In AIP Conference Proceedings (Vol. 1179, No. 1, pp. 221-224). American Institute of Physics. 
[21] Sujarwanto, E., Hidayat, A., \& Wartono, W. (2014). Kemampuan pemecahan masalah fisika pada modeling instruction pada siswa SMA kelas XI. Jurnal Pendidikan IPA Indonesia, 3(1).

[22] Mustofa, M. H., \& Rusdiana, D. (2016). Profil kemampuan pemecahan masalah siswa pada pembelajaran gerak lurus. Jurnal Penelitian \& Pengembangan Pendidikan Fisika, 2(2): 15-22.

[23] Walsh, L. N., Howard, R. G., \& Bowe, B. (2007). Phenomenographic study of students' problem solving approaches in physics. Physical Review Special Topics-Physics Education Research, 3(2): 020108 . 